\title{
WPŁYW TECHNOLOGII CLOUD COMPUTING NA ORGANIZACJE ORAZ EFEKTYWNOŚĆ PROCESU OPERACYJNEGO PLANOWANIA PRODUKCJI
}

\author{
Wojciech Kapeliński \\ Uniwersytet Ekonomiczny we Wrocławiu \\ Wydział Zarządzania, Informatyki i Finansów
}

\begin{abstract}
Streszczenie: Celem artykułu jest zaprezentowanie wpływu technologii Cloud Computing na organizację oraz efektywność procesu operacyjnego planowania produkcji. W pierwszej części artykułu autor omawia podstawowe zagadnienia dotyczące technologii Cloud Computing. Przedstawia ogólne kwestie związane z planowaniem produkcji, w szczególności z tworzeniem planów operacyjnych. W kolejnych częściach publikacji autor porusza problematykę wpływu technologii Cloud Computing zarówno na organizację, jak i efektywność omawianego procesu. Przedstawia, w jaki sposób możliwość wykorzystania systemów informatycznych opartych na technologii Cloud Computing do wspierania procesu operacyjnego planowania produkcji odbija się na organizacji oraz efektywności omawianego procesu.
\end{abstract}

Słowa kluczowe: Cloud Computing, chmura obliczeniowa, nowoczesna technologia, planowanie i harmonogramowanie produkcji, zarządzanie produkcją

DOI: 10.17512/znpcz.2016.3.1.09

\section{Wprowadzenie}

Na rynku pojawiają się nowe kierunki rozwoju aplikacji wspierających funkcjonowanie przedsiębiorstw poprzez umożliwienie im rozwoju na płaszczyźnie technologii informacyjno-komunikacyjnych. Pośród nich należy zwrócić szczególną uwagę na aplikacje wykorzystujące technologie Cloud Computing. Początkowo aplikacje te były kojarzone z prostymi rozwiązaniami, jednakże wraz z upowszechnianiem się technologii na rynku zaczęły pojawiać się bardziej zaawansowane aplikacje. Zastosowanie technologii Cloud Computing w obszarach funkcjonowania przedsiębiorstw produkcyjnych, takich jak proces operacyjnego plano-wania produkcji, umożliwiłoby łatwiejszy dostęp do systemów wspierających ten proces większej liczbie przedsiębiorstw, w szczególności organizacjom o małej i średniej wielkości.

Celem artykułu jest zaprezentowanie wpływu technologii Cloud Computing na organizację oraz efektywność procesu operacyjnego planowania produkcji. Artykuł składa się z czterech części. W pierwszej prezentowane są podstawowe założenia technologii Cloud Computing. W kolejnej zostały zawarte podstawowe zagadnienia dotyczące operacyjnego planowania produkcji w przedsiębiorstwach. Część trzecia poświęcona jest analizie wpływu chmury obliczeniowej na organizację procesu ope- 
racyjnego planowania produkcji. Natomiast ostatnia, czwarta część poświęcona jest analizie wpływu przetwarzania w chmurze na efektywność omawianego procesu.

Prezentowany w artykule wpływ technologii Cloud Computing na organizację oraz efektywność procesu operacyjnego planowania produkcji stanowi podsumowanie części wyników badań przeprowadzonych w ramach przygotowywanej przez autora rozprawy doktorskiej (Kapeliński 2016) oraz stanowi on kontynuację artykułu pt. Wykorzystanie technologii Cloud Computing w procesie operacyjnego planowania produkcji (Nowicki, Kapeliński, Burkot 2015).

\section{Wybrane założenia Cloud Computing}

Pojęcie „Cloud Computing” jest thumaczone na język polski jako „przetwarzanie w chmurze” lub „chmura obliczeniowa”. Najczęściej przytaczaną definicją jest ta podawana przez NIST (National Institute of Standards and Technology): „Cloud Computing jest modelem umożliwiającym wszechobecny, wygodny i możliwy na żądanie dostęp za pośrednictwem sieci do dzielonych zasobów obliczeniowych (tj. sieci, serwery, pamięci masowe, aplikacje i usługi), które mogą być szybko zapewnione i uwolnione przy minimalnym zarządzaniu lub ingerencji dostawcy" (Mell, Grance 2011).

W tradycyjnym środowisku przetwarzania wyodrębnia się trzy podstawowe poziomy systemu informatycznego: infrastruktura, platforma oraz aplikacja. W Cloud Computing powstały trzy odpowiadające im modele dostarczania usług. W wyniku tego podziału zostały wyodrębnione trzy podstawowe modele dostarczania usług:

- Infrastructure as a Service - infrastruktura jako usługa,

- Platform as a Service - platforma jako usługa,

- Software as a Service - oprogramowanie jako usługa.

Porównując model tradycyjny z chmurą obliczeniową, można odwołać się do analizy zaproponowanej przez The Open Group przedstawionego w opracowaniu Cloud Computing for Business (Harding 2011). Według powyższego opracowania do najważniejszych elementów wyróżniających Cloud Computing na tle tradycyjnych rozwiązań należy zaliczyć:

- możliwość dostępu do zasobów w przeciągu minut lub godzin,

- zmniejszenie początkowych nakładów inwestycyjnych,

- korzyści skali dla wszystkich użytkowników,

- multitenancy ${ }^{1}$ rozumianą jako jednoczesne użytkowanie przez wiele podmiotów tych samych zasobów,

- skalowalność,

- wirtualizację.

Ze szczegółowym opisem technologii Cloud Computing można zapoznać się w literaturze przedmiotu. Na uwagę zasługują pozycje (Lapiński, Wyżnikiewicz 2011) oraz (Velte, Velte, Elsenper 2010).

\footnotetext{
${ }^{1}$ Tłumaczone na język polski jako „wielodzierżawa” lub „wielonajem”.
} 


\section{Operacyjne planowanie produkcji}

Planowanie stanowi obok organizowania, kierowania oraz kontrolowania jedną z czterech bazowych funkcji, na której opiera się proces zarządzania. $\mathrm{W}$ działalności przedsiębiorstw planowanie produkcji jest to formułowanie celów produkcyjnych, ustalanie hierarchii ich ważności, precyzowanie zadań, które należy wykonać, oraz wyznaczanie środków niezbędnych do osiągnięcia celów. Planowanie produkcji w przedsiębiorstwach występuje na wszystkich szczeblach zarządzania i na każdej pełni ono inną rolę. Ranga i jego wpływ na kluczowe aspekty funkcjonowania przedsiębiorstwa rośnie wraz ze wzrostem szczebla zarządzania. Operacyjne planowanie produkcji (nazywane również planowaniem wykonawczym, krótkoterminowym lub harmonogramowaniem) realizowane jest na najniższym szczeblu zarządzania przedsiębiorstwa i stanowi bezpośrednie przedłużenie planu taktycznego. Powiązane jest ściśle z bieżącym funkcjonowaniem systemu produkcyjnego. Jego wynikiem jest otrzymanie planów wykonawczych bazujących na rzeczywistych zdolnościach wytwórczych przedsiębiorstwa dla wyrobów gotowych oraz jego składników (zarówno wytwarzanych, jak i kupowanych) - planowanie zadań. Planowanie w czasie (inaczej terminowanie) oraz planowanie obciążeń (inaczej bilansowanie) stanowią dwa główne elementy planowania zadań.

Podstawowym celem planów operacyjnych jest umożliwienie realizacji procesów wytwórczych związanych z otrzymanymi od klienta zamówieniami (spełnienie oczekiwań odnośnie asortymentu, ilości oraz terminów dostaw), przy stworzeniu warunków do minimalizacji kosztów wytwarzania i wysokiego stopnia wykorzystania urządzeń technologicznych. Operacyjne planowanie produkcji powinno spełniać następujące postulaty:

- skuteczności - zaspokajanie potrzeb rynkowych w realizacji bieżącej sprzedaży (asortyment, ilość, termin dostaw);

- realności - zbilansowanie z dostępnością zasobów materiałowych i zdolności produkcyjnej;

- efektywności - minimalizacja kosztów drogą racjonalnego wykorzystania zasobów.

Zadania te realizowane są poprzez odpowiednie planowanie zadań w czasie oraz bilansowanie obciążeń dostępnych zasobów produkcyjnych. Plany te ze względu na swój charakter ulegają częstym modyfikacjom i w związku z tym muszą one być elastyczne, aby móc reagować na dynamicznie zmieniające się otoczenie. Ze szczegółowym opisem operacyjnego planowania produkcji można zapoznać się w literaturze przedmiotu. Na uwagę zasługują pozycje (Jasiński (red.) 2011) oraz (Pająk 2006).

\section{Wpływ technologii Cloud Computing na organizację procesu operacyjnego planowania produkcji}

Chcąc przeanalizować wpływ technologii Cloud Computing na organizację procesu operacyjnego planowania produkcji, w pierwszej kolejności należy wyodrębnić obszary funkcjonowania przedsiębiorstwa, na jakie wpływa wykorzystanie 
chmury obliczeniowej. W pierwszej kolejności wykorzystanie przetwarzania w chmurze wpływa na strukturę zasobów informatycznych wspierających proces operacyjnego planowania produkcji. Następnie ma on wpływ na organizację samego procesu operacyjnego planowania produkcji. W tradycyjnym środowisku istotną rolę odgrywają jednostki organizacyjne odpowiedzialne na przykład za pozyskanie, zarządzanie oraz utrzymanie niezbędnych zasobów informatycznych (zarówno sprzętowych, jak i oprogramowania) wspierających proces operacyjnego planowania produkcji. Z kolei w środowisku opierającym się na technologii Cloud Computing część zadań przenoszonych jest na dostawcę rozwiązania. Po jego stronie leży między innymi ciężar zapewnienia bezawaryjnego działania, konfigurowania czy aktualizowania rozwiązania. W modelu Cloud Computing następuje przeniesienie odpowiedzialności za zarządzanie fizycznymi elementami systemu IT na operatora chmury obliczeniowej. Doprowadza to do zwolnienia działu IT z zadań związanych $\mathrm{z}$ dbaniem o niezbędną infrastrukturę sprzętową oraz oprogramowanie wymagane do zapewnienia prawidłowego funkcjonowania procesu operacyjnego planowania produkcji. Dzięki odciążeniu działu IT z powyższych zadań może on przenieść ciężar swojej działalności na wspieranie podstawowych obszarów funkcjonowania przedsiębiorstwa. $\mathrm{Z}$ drugiej strony wykorzystanie technologii Cloud Computing wpływa na organizację pracy osób odpowiedzialnych za operacyjne planowanie produkcji w przedsiębiorstwie. Ulega zmianie sposób dostępu uczestników procesu zarówno do wymaganej infrastruktury, jak i oprogramowania. W chmurze obliczeniowej dostęp do aplikacji oraz danych odbywa się z wykorzystaniem przeglądarki internetowej. Nie jest wymagane instalowanie na komputerze użytkownika żadnych dodatkowych aplikacji. Pociąga to za sobą drugą zmianę, jaką jest zapewnienie dostępu do rozwiązania $z$ dowolnego miejsca na świecie również z wykorzystaniem urządzeń mobilnych. Dzięki powyższemu założeniu możliwe staje się łatwe zaangażowanie innych podmiotów w proces operacyjnego planowania produkcji w przedsiębiorstwie. Otoczenie procesu (dostawcy, odbiorcy czy kooperanci) może posiadać dostęp do wybranych funkcjonalności rozwiązania bez konieczności stosowania specjalistycznych, zaawansowanych rozwiązań informatycznych, takich jak elektroniczna wymiana danych EDI. Doprowadza to do usprawnienia procesu pozyskiwania i przekazywania informacji, na przykład dotyczących możliwości realizacji zleceń zakupu, sprzedaży czy procesu kooperacji. Wiąże się to z możliwością zapewnienia dostępu oraz współdzielenia aktualnych danych pomiędzy wszystkimi uczestnikami procesu działającymi zarówno wewnątrz, jak i na zewnątrz przedsiębiorstwa. Wykorzystanie technologii Cloud Computing może prowadzić do skrócenia czasu realizacji procesu w wyniku zapewnienia łatwiejszego dostępu do wymaganych informacji. Wykorzystanie chmury obliczeniowej pozwala na ujednolicenie i uproszczenie procesów w przedsiębiorstwie, jednakże kosztem ich elastyczności. Istotne jest to zwłaszcza w odniesieniu do przedsiębiorstw z obszaru MŚP. 


\section{Wpływ technologii Cloud Computing na efektywność procesu operacyjnego planowania produkcji}

W analizie wpływu technologii Cloud Computing na efektywność procesu operacyjnego planowania produkcji istotną rolę odgrywa znajomość pojęcia efektywności. W niniejszych rozważaniach efektywność rozumiana jest jako kryterium oceny działalności zarówno całego przedsiębiorstwa, jak i jego poszczególnych obszarów (w omawianym przypadku operacyjnego planowania produkcji). „Efektywność jest to miara określająca relację między osiągniętymi wynikami a wykorzystywanymi zasobami” (Adamczyk 1995). W odniesieniu do projektów informatycznych ocena efektywności oparta jest na prowadzeniu rachunku ekonomicznego ułatwiającego podjęcie decyzji o wdrożeniu projektu, a po jego zakończeniu pozwala na ostateczną ocenę zrealizowanego przedsięwzięcia informatycznego poprzez przeciwstawienie wykonanym kosztom uzyskanych korzyści (Chomiak-Orsa 2010). W tym przypadku efektywność ujmowana jest jako relacja efektów do poniesionych nakładów. Efektywność może być formułowana w dwóch wariantach:

- wydajnościowym - maksymalizacja efektu,

- oszczędnościowym - minimalizacja nakładu.

Ponadto należy nadmienić, iż efektywność systemu informatycznego, aplikacji czy technologii informatycznej może być mierzona za pomocą szeregu wskaźników, np. stóp zwrotu typu ROI (Return on Investment), miar uwzględniających znacznie więcej parametrów wejściowych EVI (Expected Value of Information oczekiwana wartość informacji), MNPV (Modified Net Present Value - zmodyfikowana wartość aktualna inwestycji), NPV (Net Present Value - wartość aktualna inwestycji), MIRR (Modified Internal Rate of Return - zmodyfikowana wewnętrzna stopa zwrotu). Natomiast w przypadku identyfikacji wszystkich kosztów wykorzystywania IT można posłużyć się analizą TCO (Total Cost of Ownership), służącą do oceny bieżących i prognozowanych wydatków na infrastrukturę informatyczną (Zieliński 2010).

W niniejszej części omawiana będzie efektywność ekonomiczna nawiązująca do zasady racjonalnego gospodarowania. Wzrost efektywności w omawianym procesie możliwy jest do osiągnięcia na dwa sposoby. Pierwszym z nich jest wzrost efektów procesu operacyjnego planowania produkcji. Wzrost ten może mieć miejsce w wyniku omawianych powyżej zmian organizacji wynikających z zastosowania chmury obliczeniowej. $\mathrm{Z}$ drugiej strony dzięki zastosowaniu przetwarzania w chmurze wzrost efektywności można uzyskać w drodze ograniczenia nakładów poniesionych na obsługę procesu operacyjnego planowania produkcji w przedsiębiorstwie realizowaną poprzez zmianę struktury ponoszonych przez przedsiębiorstwo kosztów. W Tabeli 1 zostały zaprezentowane, a następnie omówione podstawowe czynniki mające wpływ na efektywność procesu operacyjnego planowania produkcji. W modelu tradycyjnym, jak i w modelu Cloud Computing są nimi nakłady inwestycyjne oraz ponoszone koszty działalności operacyjnej przedsiębiorstwa. 
Tabela 1. Wpływ technologii Cloud Computing na efektywność procesu operacyjnego planowania produkcji

\begin{tabular}{|c|c|c|}
\hline Czynnik & Model tradycyjny & Model Cloud Computing \\
\hline $\begin{array}{l}\text { Nakłady } \\
\text { inwestycyjne }\end{array}$ & $\begin{array}{l}\text { Wymagane nakłady } \\
\text { inwestycyjne na: } \\
\text { - sprzęt IT, w tym serwery } \\
\text { - licencje IT } \\
\text { - sieci }\end{array}$ & $\begin{array}{l}\text { Wymagane nakłady inwestycyjne na: } \\
\text { - lokalny sprzęt IT zapewniający dostęp } \\
\text { usługi w modelu Cloud Computing } \\
\text { - licencje IT - brak jednorazowego } \\
\text { wydatku w przypadku modelu SaaS; } \\
\text { w przypadku modelu IaaS występują } \\
\text { nakłady na wybrane licencje IT, takie } \\
\text { jak systemy operacyjne, licencje opro- } \\
\text { gramowania, pakiety biurowe } \\
\text { - dostęp do sieci Internet o wysokiej } \\
\text { przepustowości }\end{array}$ \\
\hline $\begin{array}{l}\text { Koszty } \\
\text { dzialalności } \\
\text { operacyjnej }\end{array}$ & $\begin{array}{l}\text { Koszty utrzymania: } \\
\text { - sprzęt IT, w tym serwery } \\
\text { - licencje IT } \\
\text { - sieci } \\
\text { - zasoby ludzkie }\end{array}$ & $\begin{array}{l}\text { Koszty utrzymania: } \\
\text { - lokalny sprzęt IT zapewniający dostęp } \\
\text { usługi w modelu Cloud Computing } \\
\text { Koszty ponoszone za wykorzystane: } \\
\text { - moce obliczeniowe } \\
\text { - przechowywanie danych } \\
\text { - transmisje danych } \\
\text { - licencje }\end{array}$ \\
\hline
\end{tabular}

Źródło: Opracowanie własne

Korzyścią wdrożenia chmury obliczeniowej z pozycji przedsiębiorstwa jest zamiana wysokich nakładów inwestycyjnych na koszty operacyjne w postaci opłaty dla dostawcy rozwiązania. $Z$ punktu widzenia przedsiębiorstwa nie są ponoszone nakłady inwestycyjne, a cykliczne (np. comiesięczne) koszty bieżącej działalności. Prowadzi to do ograniczenia poziomu nakładów inwestycyjnych ponoszonych na sprzęt IT (w tym serwerownie), licencję IT oraz infrastrukturę sieciową. Analogicznie zmieniają się koszty ponoszone na działalność operacyjną przedsiębiorstwa. Prowadzi to do eliminacji niektórych kategorii kosztowych, ale również powstania nowych. Przy czym kalkulacja całkowitych kosztów powinna zawierać wymienione poniżej elementy (Aggarwal, McCabe 2009):

- eksploatacja serwerów i dysków pamięci masowych; wydatki inwestycyjne poniesione na nabycie baz danych, aplikacji, środowisk testowych; koszty operacyjne ponoszone na przestrzeń dyskową, energię i chłodzenie;

- eksploatacja baz danych, systemów bezpieczeństwa i wsparcia oprogramowania; wydatki inwestycyjne poniesione na nabycie: systemów operacyjnych, programów antywirusowych;

- koszt pozyskania i utrzymania odpowiednich kompetencji ludzkich w zakresie administrowania architekturą IT. 
Przedsiębiorstwo nie ponosi już kosztów związanych z utrzymaniem infrastruktury oraz działu IT czy kosztów utrzymania oprogramowania (ang. maintenance). Pojawiają się za to nowe rodzaje kosztów, takie jak opłaty za dostarczenie usług w chmurze czy wzrost zapotrzebowania na transmisję danych. Najważniejszym czynnikiem wpływającym na obniżenie nakładów inwestycyjnych jest zmniejszenie ponoszonych kosztów rzeczywistego wykorzystania usług. W tym wypadku przedsiębiorstwo ponosi periodyczny koszt rozliczany, w zależności od modelu chmury, za zużycie/obciążenie systemu, wykorzystanie przestrzeni dyskowej czy liczby licencji. W związku $\mathrm{z}$ tym przedsiębiorstwo może reagować dynamicznie na zmieniające się zapotrzebowanie na zasoby wynikające np. z sezonowości produkcji, co prowadzi do obniżenia ponoszonych kosztów.

Wdrożenie rozwiązania wykorzystującego przetwarzanie w chmurze oferuje przedsiębiorstwom możliwość ograniczenia czasu określanego mianem TTM (ang. Time To Market). TTM mierzy czas niezbędny do implementacji nowej aplikacji bądź wejścia na rynek z nową usługą czy produktem. Obniżenie tego czasu ogranicza ponoszone przez przedsiębiorstwo koszty oraz zwiększa jego przewagę konkurencyjną poprzez umożliwienie dynamicznego reagowania na zachodzące na rynku zmiany. Długość okresu pomiędzy inicjatywą biznesową a faktycznym uruchomieniem docelowego pomysłu zależy od kilku czynników, do których zaliczyć można (Pazowski 2014):

- posiadanie odpowiedniego sprzętu i oprogramowania,

- czas pozyskania niezbędnego know-how,

- szybkość przeprowadzenia wdrożenia.

Technologia Cloud Computing może prowadzić do obniżenia TTM poprzez dostarczenie niezbędnych zasobów sprzętowych w przeciągu godzin, a nawet minut (model IaaS) oraz minimalizować czas przeprowadzanego wdrożenia poprzez oferowanie ustandaryzowanych, predefiniowanych rozwiązań. Szybkość wdrażania nowych rozwiązań informatycznych pozwala na ograniczenie kosztów alternatywnych, często nazywanych kosztami potencjalnie utraconych możliwości, wynikających z niepodjęcia określonych działań. W omawianym przypadku koszt alternatywny stanowić mogą środki przeznaczone na utrzymanie własnej infrastruktury IT, które mogłyby być przeznaczone na podstawową działalność przedsiębiorstwa.

\section{Podsumowanie}

Technologia Cloud Computing jest coraz powszechniej wykorzystywana w przedsiębiorstwach krajowych i międzynarodowych. Użycie technologii Cloud Computing w poszczególnych przedsiębiorstwach zależy od zastosowanych w nich rozwiązań strukturalnych i funkcjonalnych. W chwili obecnej stała się już standardowym rozwiązaniem służącym do przechowywania poczty, danych czy zdjęć wraz z posiadaniem do nich dostępu za pomocą dowolnego urządzenia, takiego jak komputer stacjonarny, laptop, tablet, smartfon. W najbliższych latach popularność chmury będzie rosła wraz z rozwojem technologii mobilnych, rozwiązań bezprzewodowych oraz potrzeby przechowywania coraz większej ilości danych. Dużą szansą dla rozwiązań z dziedziny Cloud Computing stanowić będzie administracja 
publiczna. W chmurze obliczeniowej swoje własne rozwiązania oferują już nie tylko zagraniczne globalne przedsiębiorstwa. Również polskie firmy rozszerzają swoje oferty o produkty wykorzystujące technologię Cloud Computing. Przykładowo firma Comarch posiada usługę Comarch Cloud Computing. Oferuje w chmurze własne aplikacje, takie jak systemy klasy ERP, usługi księgowe, e-Commerce, kopie zapasowe danych. Bazując na swoich doświadczeniach, przewiduje ona, że „dzięki wykorzystaniu chmury IT oszczędności przedsiębiorstw wynoszą w pierwszym roku od 30\% do 50\% - w zależności od wymagań funkcjonalnych i wielkości firmy. Również w 5-letnim ujęciu inwestycji wybór chmury okazuje się opłacalny, w szczególności dla mikro oraz małych firm" (http://www.icomarch24.p1/ nasza_chmura). Obrazuje to ogólny trend na ogólnoświatowym rynku. „Ponad $60 \%$ europejskich małych i średnich przedsiębiorstw przeniosło już część swej infrastruktury do chmury. Na tym tle Polska wypada trochę słabiej, ale już $46 \%$ firm z sektora MŚP korzysta z technologii Cloud Computing” (Skowera 2012). Przy czym większość powyższych rozwiązań stanowią proste aplikacje biurowe. „Według szacunków w 2020 roku tylko w Stanach Zjednoczonych korzystanie z chmury pozwoli oszczędzić około 12 miliardów dolarów, które mogłyby zostać wydane na opłacenie energii elektrycznej. W 2009 roku wartość rynku Cloud Computing warta była około 56 miliardów dolarów" (Skowera 2012).

\section{Literatura}

1. Adamczyk J. (1995), Efektywność przedsiębiorstw sprywatyzowanych, Wydawnictwo Akademii Ekonomicznej w Krakowie, Kraków.

2. Aggarwal S., McCabe L. (2009), The Compelling TCO Case of Cloud Computing in SMB and Mid-Market Enterprises, Hurwitz \& Assiociates, Needham.

3. Chomiak-Orsa I. (2010), Kryteria wyboru wdrażanych rozwiąań informatycznych, [w: Knosala R. (red.), Komputerowo zintegrowane zarzadzanie, t. 1, Oficyna Wydawnicza Polskiego Towarzystwa Zarządzania Produkcją, Opole.

4. Harding C. (2011), Cloud Computing for Business, The Open Group, United Kingdom, http://www.opengroup.org/sites/default/files/contentimages/Press/Excerpts/first_ 30 pages.pdf (dostęp: 30.06.2016).

5. http://www.icomarch24.pl/nasza_chmura (dostęp: 17.03.2013).

6. Jasiński Z. (red.) (2011), Podstawy zarzadzania operacyjnego, Wolters Kluwer, Warszawa.

7. Kapeliński W. (2016), Model systemu informatycznego wspomagania decyzji w procesie operacyjnego planowania produkcji $z$ wykorzystaniem technologii Cloud Compuiting, Uniwersytet Ekonomiczny we Wrocławiu, Wrocław, (maszynopis niepublikowany).

8. Kisielnicki J. (2008), Systemy informatyczne zarządzania, Agencja Wydawnicza Placet, Warszawa.

9. Łapiński K., Wyżnikiewicz B. (2011), Raport Cloud Computing. Wpływ na konkurencyjność przedsiębiorstw i gospodarke polski, Instytut Badań nad Gospodarką Rynkową, Warszawa.

10. Mell P., Grance T. (2011), The NIST Definition of Cloud Computing, US Department of Commerce.

11. Nowicki A., Kapeliński W., Burkot B. (2015), Wykorzystanie technologii Cloud Computing w procesie operacyjnego planowania produkcji, [w:] Pawełoszek I., Stępniak C. (red.), Wiedza w przedsiębiorczości - aspekty technologiczne, organizacyjne i społeczne, Sekcja Wydawnictw Wydziału Zarządzania Politechniki Częstochowskiej, Częstochowa. 
12. Pająk E. (2006), Zarządzanie produkcją, Produkt, technologia, organizacja, Wydawnictwo Naukowe PWN, Warszawa.

13. Pazowski P. (2014), Ekonomiczne aspekty wdrożenia modelu Cloud Computing, „Modern Management Review", Vol. 19, No. 21.

14. Skowera P. (red.) (2012), Cloud Computing. Historia, technologia, perspektywy, PARP, Warszawa.

15. Velte A.T., Velte T.J., Elsenper R., Cloud Computing: A Practical Approach, McGraw-Hill Companies.

16. Zieliński Z. (2010), Rola informatyki w naukach ekonomicznych i społecznych, Wyższa Szkoła Handlowa w Kielcach, Kielce.

\title{
IMPACT OF CLOUD COMPUTING TECHNOLOGY ON THE ORGANIZATION AND EFFICIENCY OF OPERATIONAL PRODUCTION PLANNING
}

\begin{abstract}
The aim of this article is to present the impact of Cloud Computing technology on the organization and efficiency of operational production planning. In the first part of the article the author discusses basic issues related to the Cloud computing technology. It presents general issues related to the production planning process, in particular to the creation of operational plans. In the following parts of the publication author describes of the impact of Cloud Computing technology on the organization and efficiency of this process. It shows how the ability to use systems based on the technology of Cloud Computing is reflected in the organization and efficiency of discussed process.
\end{abstract}

Keywords: Cloud Computing, production planning and scheduling, manufacturing management, new technologis 